\title{
FUNCTIONAL OUTCOMES OF ARTHROSCOPIC TREATMENT IN 230 FEMOROACETABULAR IMPINGEMENT CASES
} FUNCTIONAL RESULT OF ARTHROSCOPIC TREATMENT
IN 230 IMPACTS FEMOROACETABULARES

\author{
Gerson Muraro Laurito ${ }^{1}$ (i), Flavio Leite Aranha Junior ${ }^{1}$ (i), SÉrgio Rocha Piedade ${ }^{1}$ (1)
}

1. Sports and Exercise Medicine Group, Department of Orthopedics, Rheumatology and Traumatology (DORT), School of Medical Sciences, University of Campinas-UNICAMP, Campinas, SP, Brazil.

\section{ABSTRACT}

Objective: To analyze the functional outcomes after arthroscopic treatment of femoroacetabular impingement (FAl). Methods: 194 patients (131 males and 63 females), with a mean age of 39 (15-68) years old for men and 43 (16-58) years old for women. The average follow-up was 17 months (2 to 71). 103 patients presented Cam-type FAI, 102 mixed and 25 Pincer. "Unilateral" arthroscopy was performed in 161 cases, "Bilateral" (only once each side) in 46 cases and, "Multiple" (more than one procedure on the same hip) in 23. The female sex was prevalent in the Pincer type FAI (76\%), while males were prevalent in Mixed and Cam type, $74.5 \%$ and $72.8 \%$, respectively. Results: The mean HHSpre score was 63.7 and 87.1 for HHSpost, i.e. 73.11\%. Differences appeared between "mixed" and "unilateral" groups. The complications percentage in this series was $18.7 \%$ and $7 \%$ progressed to total hip arthroplasty. Conclusion: The arthroscopic FAl treatment improved the postoperative clinical scores of these patients, especially in cases of mixed-type FAl, which presented a higher improvement rate. Insufficient femoral osteoplasty was the main cause for surgical re-intervention, particularly in the initial cases of this series. Level of Evidence II, Retrospective study.

Keywords: Femoroacetabular Impingement. Arthroscopy. Hip. Patient Reported Outcome Measures.

\section{RESUMO}

Objetivo: Avaliar os resultados funcionais após tratamento artroscópico do impacto femoroacetabular (IFA). Métodos: Foram selecionados 194 pacientes (131 do sexo masculino e 63 do sexo feminino), com idade média de 39 (15-68) anos no caso dos homens e 43 (16-58) anos para as mulheres. O seguimento médio foi de 17 meses (2 a 71). 103 pacientes apresentaram IFA tipo Came, 102 Misto e 25 tipo Pincer. A artroscopia única foi realizada em 161 casos; a bilateral (somente uma vez cada lado) em 46 casos e a múltipla (mais de um procedimento no mesmo quadril) em 23. O sexo feminino foi prevalente no IFA do tipo Pincer (76\%) e o masculino nos tipos Misto e Came, 74,5\% e $72,8 \%$, respectivamente. Resultados: A média do escore HHSpré foi de 63,7 para HHSpós de 87,1, ou seja 73,11\% Ficaram evidenciadas diferenças nos grupos "misto" e "único". O percentual de complicações desta série foi de 18,7\% e 7\% evoluíram para artroplastia total do quadril. Conclusão: O tratamento artroscópico IFA melhorou os escores clínicos, principalmente nos casos de IFA do tipo misto, que apresentou maior taxa de melhora, A osteoplastia femoral insuficiente foi a principal causa para reintervenção cirúrgica, particularmente nos casos iniciais desta série. Nível de Evidência II, Estudo retrospectivo.

Descritores: Impacto Femoroacetabular. Artroscopia. Quadril. Medidas de Resultados Relatados pelo Paciente.

Citation: Laurito GM, Aranha FL Jr, Piedade SR. Functional outcomes of arthroscopic treatment in 230 femoroacetabular impingement. Acta Ortop Bras. [online]. 2021;29(2):67-71. Available from URL: http://www.scielo.br/aob.

\section{INTRODUCTION}

Although femorocetabular impingement (FAl) represents one of the most common causes of hip pain in young adults, ${ }^{1}$ the first conceptual descriptions of $\mathrm{FAl}^{2}$ were made in 1991 and, in 2003, Ganz et al. ${ }^{3}$ described its clinical implications. Being a relatively recent pathology ${ }^{4}$ may contribute to its misdiagnosis by generalist orthopedists, particularly in the initial stages of the disease.
According to the morphological alteration, FAl can be classified as Cam-type, if the alterations appear in the femoral head-neck junction (prominence in the neck-head transition); Pincer, when the alterations are in the acetabulum (acetabular overcoverage of the femoral head); and Mixed, when there is an association between the two previous types. ${ }^{5}$ These abnormal anatomical relationships, as well as possible supraphysiological movements ${ }^{6}$ (even if morphology is normal),

All authors declare no potential conflict of interest related to this article.

The study was conducted at Exercise and Sports Medicine Group, Department of Orthopedics, Rheumatology and Traumatology, Universidade Estadual de Campinas. Correspondence: Sérgio Rocha Piedade. Rua Severo Penteado, 131, apto. 1, Campinas, SP, Brazil, 13025050. piedade@unicamp.br 
can produce shear and contact forces between the transition of the head and femoral neck with the acetabulum. The evolution of the disease can lead to labral tears, chondral lesions or a combination of both - chondro-labral transition-and, consequently, hip osteoarthritis. These observations are important, because FAl can affect young adults in their productive age, directly interfering in quality of life. Although open surgeries are sometimes recommended to treat $\mathrm{FAI}$, minimally invasive procedures are desired objectives in all surgical specialties, due to their lower morbidity and length of hospitalization, which allow a faster process of functional rehabilitation. ${ }^{7}$ Within this context, the arthroscopic approach of the hip is an interesting surgical alternative, because it can contemplate the advantages of less surgical trauma, modify the symptomatic picture and thus contribute to slow down the evolutionary process of osteoarthritis. ${ }^{8,9}$

Hip arthroscopy is, however, a procedure with specificities that reinforce the importance of proper surgical preparation, particularly the correct positioning of the patient on the operating table and use of traction. ${ }^{9}$ These are essential measures, as they widen the joint space and favor the correct identification of anatomical references and placement of arthroscopic portals. Thus, the arthroscopic approach of the hip combines a series of technical details that are incorporated and improved with technical development and surgical experience. ${ }^{10,11}$

The aim of this retrospective study was to evaluate functional results after the arthroscopic approach of FAI in a series of patients; to correlate the three types of FAI (Cam, Mixed and Pincer) with variables such as age, sex, type of arthroscopic surgery (Unilateral, Bilateral or Multiple) and complications; as well as presenting the acquired experience in the study.

\section{MATERIALS AND METHODS}

This retrospective study evaluated 230 arthroscopic hip surgeries that were performed from June 2006 to September 2013. The sample comprised 194 patients - 63 women (32.5\%), 131 men $(67.5 \%)(p=0.3044)$ - with a mean age of 43 years old (16 to 58 ) for women and 39 years old ( 15 to 68 ) for men ( $p=0.5172$ ). The mean follow-up was 17 months (2 to 71$)$. The FAl diagnosis was Cam in 103 patients (44.78\%), Mixed in 102 (44.34\%) and Pincer in 25 (10.87\%). In $70 \%$ of the cases $(n=161)$ a unilateral approach was performed; bilateral $(n=46)$ in $20 \%$; and multiple in $10 \%(n=23)$ (Table 1).

Table 1. Distribution of the 230 cases according to the different types of femoroacetabular impingement and arthroscopic surgery performed.

\begin{tabular}{c|c|c|c|c}
\hline & \multicolumn{3}{|c|}{ Type of surgery } & \\
\hline Type of FAl (\%) & Bilateral & Multiple & Unilateral & Total \\
\hline Cam & 18 & 10 & 75 & 103 \\
\hline Mixed & 25 & 12 & 65 & 102 \\
\hline Pincer & 3 & 1 & 21 & 25 \\
\hline Total & 46 & 23 & 161 & 230 \\
\hline
\end{tabular}

Clinical history data, physical and functional examination of the patients were also recorded. In this series, the main reported complaint was hip pain associated with movement limitation, followed by restriction to practice physical activities. The adopted criteria for surgical indication were defined based on clinical and radiographic evaluation. The included patients were diagnosed with FAI, had been submitted to hip arthroscopy and presented up to grade 2 of joint degeneration in the Tönnis classification. ${ }^{12}$

Patients had good general health (ASA I or II), practiced regular physical activities and had no history of previous surgical procedures. The main complaint was progressive and limiting hip pain. The procedures were ambulatory, performed in a standardized way by two surgeons (GML and FLAJr). We excluded patients whose medical records did not allow these analyses - grade 3 of degeneration (Tönnis classification) (Chart 1). The Informed Consent Form was obtained from all patients, and the study was submitted and approved by the Ethics Committee of this service (CAAE: 38413414.1.0000.5404; opinion no.: 980.263).

\begin{tabular}{|c|l|}
\hline \multicolumn{2}{|l|}{ Chart 1. Tönnis classification. } \\
\hline Degree & \multicolumn{1}{c|}{ Characteristics } \\
\hline Zero & No signs of osteoarthritis or minimal sclerosis. \\
\hline 1 & $\begin{array}{l}\text { Slight sclerosis of the acetabulum or femoral head, slight narrowing } \\
\text { of joint space, subtle osteophytes. }\end{array}$ \\
\hline 2 & $\begin{array}{l}\text { Small cysts in the femoral head or acetabulum, increased narrowing } \\
\text { of joint space, formation of osteophytes, moderate loss of sphericity } \\
\text { of the femoral head. }\end{array}$ \\
\hline 3 & $\begin{array}{l}\text { Larger cysts, severe narrowing or obliteration of joint space, severe } \\
\text { deformity of the femoral head, avascular necrosis. }\end{array}$ \\
\hline
\end{tabular}

\section{Statistical Analysis}

Data analysis compared the groups Type of FAI (Cam, Mixed and Pincer) and Type of arthroscopic surgery performed (Unilateral, Bilateral and Multiple). For statistical analysis, a mixed linear model was adjusted, in which the response variable (dependent) was the improvement percentage and the independent variables (age, sex, diagnostic group, type of FAl) acted as second-order interactions between categorical variables. These variables constituted the fixed effects on the adjustment of the model. As some patients were operated more than once, there is statistical dependence between the responses observed in the same patient, so the random factor 'patient' was introduced in the model. The covariance structure used was 'variance components' that were estimated by the restricted maximum likelihood (REML) method, with the approximation of Satterthwaite to the degrees of freedom; and the matrix of variances and covariances of the estimated fixed and random effects was inflated by the method proposed by Prasad-Rao (1990) and Harville-Jeske (1992). For multiple comparison of mean, the significance levels were corrected by the Tukey method to maintain the overall significance level. Residue analysis was performed to verify possible outliers.

\section{RESULTS}

The overall functional evaluation of the postoperative global functional (Harris Hip Score - HHS) showed a 73.11\% improvement (87.12) compared with preoperative mean values (63.70). This improvement was significant in the final results both for FAI $(p=0.0128)$ and for surgery $(p=0.0111)$. Similarly, the analysis of the improvement percentage was significant for 'type of FAl' $(p=0.0197)$ and 'type of surgery performed' ( $p=0.0523$ ).

No significant interactions were identified between the two studied groups (FAl and Surgery) ( $p=0.2323$ ) and in the correlation between the levels of each group, the frequency distributions did not differ from each other ( $p=0.2485)$.

Table 2 shows the distribution of mean, minimum and maximum values of age, sex and functional scores of the hip - Harris Hip Score (HHS) (preoperative, postoperative and improvement \%) in the various types of FAl, while Table 3 relates these variables to the type of surgery performed (unilateral, bilateral and multiple). Figures 1 and 2 present the analysis of the means of the least squares and standard deviations related to the type of FAl and type of surgery, respectively. Tables 4 and 5 report, respectively, 
the various procedures performed and the complications $43(18.7 \%)$ in the 230 analyzed cases. It is worth mentioning that in 16 (7\%) cases unfavorable clinical evolution led to total hip arthroplasty. The residue analyses showed no noteworthy deviations.

Table 2. Distribution of cases in the femoroacetabular impingement type group related to age, sex and hip functional score (Harris Hip Score - HHS) in the 230 evaluated cases.

\begin{tabular}{c|c|c|c|c|c}
\hline & & & \multicolumn{3}{|c}{ functional hip score (HHS) } \\
\hline $\begin{array}{c}\text { Type of } \\
\text { FAl (\%) }\end{array}$ & $\begin{array}{c}\text { Mean age } \\
\text { (min. and } \\
\text { max.) }\end{array}$ & $\begin{array}{c}\text { sex } \\
\text { (number } \\
\text { of cases) }\end{array}$ & $\begin{array}{c}\text { preoperative } \\
\text { (min. and } \\
\text { max.) }\end{array}$ & $\begin{array}{c}\text { postoperative } \\
\text { (min. and } \\
\text { max.) }\end{array}$ & improvement \% \\
\hline $\begin{array}{c}\text { Cam } \\
(103)\end{array}$ & $\begin{array}{c}40.11 \\
(17 \text { to 68) }\end{array}$ & M75 / F28 & $\begin{array}{c}63.10 \\
(36.3 \text { to } 73.7)\end{array}$ & $\begin{array}{c}88.78 \\
(15.40 \text { to 100.1) }\end{array}$ & 34.25 \\
\hline $\begin{array}{c}\text { Mixed } \\
(102)\end{array}$ & $\begin{array}{c}38.22 \\
(15 \text { to 77) }\end{array}$ & M76 / F26 & $\begin{array}{c}64.44 \\
(30.8 \text { to } 84.7)\end{array}$ & $\begin{array}{c}89.42 \\
(10.10 \text { to 100.1) }\end{array}$ & 38.76 \\
\hline $\begin{array}{c}\text { Pincer } \\
(25)\end{array}$ & $\begin{array}{c}40.56 \\
(22 \text { to 56) }\end{array}$ & M6 / F19 & $\begin{array}{c}63.14 \\
(24.2 \text { to } 84.7)\end{array}$ & $\begin{array}{c}87.38 \\
(18.70 \text { to 100.1) }\end{array}$ & 38.39 \\
\hline & $p$-value & & & & $p=0.0378$ \\
\hline
\end{tabular}

${ }^{*} \mathrm{M}$ (male) / F (female)

Table 3. Distribution of cases according to type of arthroscopic hip surgery related to age, sex and functional score (Harris Hip Score - HHS) in the 230 evaluated cases.

\begin{tabular}{c|c|c|c|c|c}
\hline \multicolumn{3}{|c|}{} & \multicolumn{3}{|c}{ functional hip score (HHS) } \\
\hline Surgery & $\begin{array}{c}\text { Mean age } \\
\text { (min. and } \\
\text { max.) }\end{array}$ & Sex & $\begin{array}{c}\text { Preoperative } \\
\text { (min. and } \\
\text { max.) }\end{array}$ & $\begin{array}{c}\text { Postoperative } \\
\text { (min. and } \\
\text { max.) }\end{array}$ & Improvement \% \\
\hline $\begin{array}{c}\text { Unilateral } \\
\text { (161) }\end{array}$ & $\begin{array}{c}41 \\
(16 \text { to 68) }\end{array}$ & M108/ F53 & $\begin{array}{c}63.56 \\
(24.2 \text { to } 84.7)\end{array}$ & $\begin{array}{c}88.47 \\
(10.1 \text { to } 100.1)\end{array}$ & 39.38 \\
\hline $\begin{array}{c}\text { Bilateral } \\
\text { (46) }\end{array}$ & $\begin{array}{c}36 \\
(15 \text { to } 55)\end{array}$ & M32/ F14 & $\begin{array}{c}65.95 \\
(42.9 \text { to } 73.7)\end{array}$ & $\begin{array}{c}89.21 \\
(38.10 \text { to } 100.1)\end{array}$ & 35.26 \\
\hline $\begin{array}{c}\text { Multiple } \\
\text { (23) }\end{array}$ & $\begin{array}{c}34 \\
(17 \text { to 49) }\end{array}$ & M17/ F6 & $\begin{array}{c}60.21 \\
(30.8 \text { to } 84.7)\end{array}$ & $\begin{array}{c}73.51 \\
(15.40 \text { to 100.1) }\end{array}$ & 22.08 \\
\hline & $p$-value & & & & $p=0.078$ \\
\hline
\end{tabular}

${ }^{*} \mathrm{M}$ (male) / $\mathrm{F}$ (female)

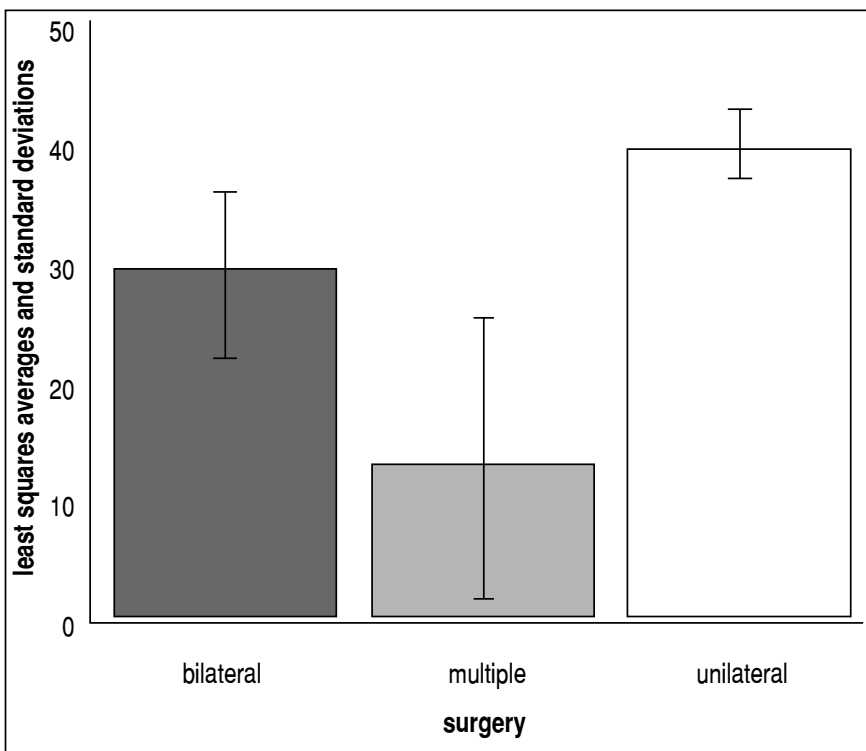

Figure 1. Distribution of the means of the least squares and standard deviations in the type of surgery group.

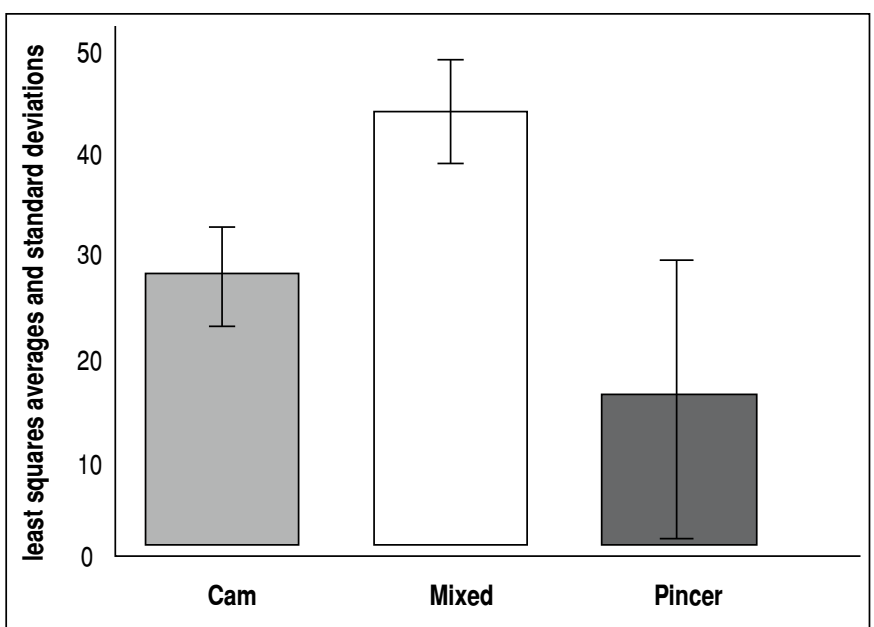

Figure 2. Distribution of least squares and standard deviations in the Femoroacetabular Impingement (FAI) type group.

Table 4. Procedures performed in the arthroscopic surgery, in the 230 cases.

\begin{tabular}{c|c}
\hline Procedure & total \\
\hline Labrum stabilization & 8 \\
\hline Labral debridement & 157 \\
\hline Labral fixation & 48 \\
\hline Acetabular osteoplasty & 133 \\
\hline Femoral osteoplasty & 193 \\
\hline Round ligament debridement & 3 \\
\hline Microfracture & 20 \\
\hline Loose bodies & 8 \\
\hline Others & 5 \\
\hline Total & 575
\end{tabular}

Table 5. Number of cases and percentage of postoperative complications.

\begin{tabular}{c|c}
\hline Complications & number of cases $\mathbf{1 8 . 7} \%$ \\
\hline Capsulitis & $3(6.9 \%)$ \\
\hline Femoral neck fracture & $1(2.3 \%)$ \\
\hline Instability & $2(4.6 \%)$ \\
\hline Skin injury & $7(16.2 \%)$ \\
\hline Neuropraxia & $17(39.5 \%)$ \\
\hline Heterotopic ossification & $13(30.2 \%)$ \\
\hline Total & $43(100 \%)$ \\
\hline
\end{tabular}

\section{DISCUSSION}

The most important finding of this study was the confirmation that arthroscopic treatment of femoroacetabular impingement (FAl) resulted in the overall improvement of the preoperative clinical condition of these patients (73.11\% of improvement), especially in mixed-type FAI cases; patients submitted to a single intervention (surgery) presented high suspicion in the improvement percentage compared with multiple surgery cases. Insufficient femoral osteoplasty was the main cause for surgical re-intervention, particularly in the initial cases of this series. Since the publications of Smith-Petersen ${ }^{13}$ in 1936, and Tönnis and Heinecke ${ }^{14}$ in 1999, and subsequently Ganz descriptions, 2,3,5 the bone morphology of the hip has been related to Femoroacetabular Impact. With the advances of the arthroscopic technique, described by Glick et al., ${ }^{15}$ this procedure has become increasingly popular in the orthopedic field.

One commonly used criterion in the surgical treatment of FAl is the classification of the hip joint degenerative state (Tönnis classification). ${ }^{16}$ 
However, in this study, radiographic classification was not the only parameter, as we also considered data on medical history, clinical examination and functional demand of patients. ${ }^{15}$

Zhang et al. ${ }^{17}$ performed a meta-analysis to evaluate the results of arthroscopic and open surgical treatment of FAI. The authors observed that the arthroscopic approach showed significant clinical improvement in the first 3 postoperative months compared with open surgery.

In the interpretation of the final results, the functional evaluation of the hip is fundamental. In clinical practice, the modified Harris Hip Score functional score (HHSm) is a commonly employed method, followed by the Hip Outcome Score (HOS).

In this study, the mean functional scores (HHS) before and after surgery showed no difference in the distribution between the different types of FAI ( $p=0.1381)$ and the number of surgical procedures $(p=0.2485)$. Similarly, statistical analysis showed no influence of the variables sex $(p=0.304)$ and age $(p=0.517)$ on the results. Considering the percentage of functional improvement in the different FAl (Table 2), the mixed type presented the highest significant $(p=0.0378)$ percentage (38.76\%) compared with Cam (34.35\%), while no differences were detected between Cam vs. Pincer and Mixed vs. Pincer. These findings may, in part, reflect more complex and comprehensive surgical attitudes (femoral and acetabular osteoplasty, for example), commonly necessary in mixed type FAl. The number of surgical interventions performed and medical history ${ }^{18}$ is considered by many authors as factors that can negatively interfere in final results. In this study, the improvement percentage regarding the number of surgical procedures showed high suspicion (marginally significant) for cases of only a single unilateral procedure compared with cases of multiple procedures $(p=0.078)$ while bilateral vs. multiple and bilateral vs. unilateral were not different. A possible explanation for these findings is that cases of a single surgical approach and the lack of symptomatology in the contralateral hip may have contributed to a better overall evaluation, because the functional hip score (HHS) has an important subjective component, that is, information reported by the patient.

An important aspect to be emphasized is that most of the morphological alterations of the hip occur during childhood, therefore, FAl is a pathology that mainly affects young adults. ${ }^{4}$ In this study, a predominance of young male patients with Cam-type IFA was observed, while in Pincer cases (10.87\% of all cases) the female sex was prevalent, a fact that is in agreement with the literature (Table 2). ${ }^{8,19}$ Postoperative follow-up time is essential to evaluate the results of the intervention. In this study, the average postoperative follow-up time was 17 months, ranging from 2 to 71 months. The shortest postoperative follow-up time (between 2 and 3 months) occurred in $6.96 \%$ of the cases (16 patients), mostly because these patients were from other cities and due to the difficulties inherent to their displacement, they began follow-up in another service, after reestablishment of joint function and postoperative clinical improvement. Even though the literature reports studies in which the analyzed follow-up time was two weeks, ${ }^{20}$ considering the minimum follow-up time of 06 months may be more appropriate for results evaluation. Regarding the distribution of sex and age, Frank et al. ${ }^{21}$ reported that women over 45 have worse outcomes, while McCormick et al. ${ }^{22}$ concluded that patients under the age of 40 have better evolution (better predictive factor). Even though men were predominant in this study, sex and age did not interfere in the final results.

In these 230 cases, 575 procedures were performed (Table 4), with femoral osteoplasty being the most frequently performed procedure (193 times), followed by labral debridement (157 times) and acetabular osteoplasty (133 times).

Insufficient femoral osteoplasty was the main cause for surgical re-intervention, particularly in the initial cases of this series. In the learning curve of the arthroscopic approach of FAI, the clinical evaluation and the careful interpretation of postoperative radiographs were fundamental for the technical and surgical strategy improvement, unlike the intraoperative interpretations made with the image intensifier.

In the evolution of the surgical approach, the mastery of the labral suture technique was improved with surgical experience and availability of materials with specific designs. In this procedure, the suture technique was consolidated from 2010.

Although the $18.7 \%$ complication rate presented in this study is above literature values, ${ }^{23}$ it should be emphasized that this study considered minor complications, that is, small skin lesions, neuropraxias without definitive repercussions and small images of heterotopic ossifications that did not harm the final result (Table 5). The limitations of this study lie in the fact that it is a retrospective case study, in which a small percentage of patients $(6.96 \%)$ had minimal follow-up between 2 and 3 months. However, it is important to consider the relevant points of this study, which are expressive serial analyses of $\mathrm{FAl}$ cases $(n=230)$, approached by the same surgeons (G.M.L and F.L.A.Jr) in a standardized way; respecting technical criteria established in the current literature.

\section{CONCLUSION}

Arthroscopic treatment of femoroacetabular impingement (FAl) resulted in the improvement of postoperative clinical scores of these patients, especially in mixed FAl cases; patients submitted to a single intervention (surgery) presented high suspicion in the improvement percentage when compared with cases of multiple surgery. Insufficient femoral osteoplasty was the main cause for surgical re-intervention, particularly in the initial cases of this series.

AUTHORS' CONTRIBUTIONS: Each author contributed individually and significantly to the development of this article. GML: surgery performance, data collection and writing, review; FLAJ: surgery, data collection and writing; SRP: data analysis and writing, review and intellectual conception of the article.

\section{REFERENCES}

1. Diaz-Ledezma C, Parvizi J. Surgical approaches for cam femoroacetabular impingement: the use of multicriteria decision analysis. Clin Orthop Relat Res. 2013;471(8):2509-16

2. Ganz R, Bamert $P$, Hausner $P$, Isler B, Vrevc F. Cervico-acetabular impingement after femoral neck fracture. Unfallchirurg. 1991;94(4):172-5.

3. Ganz R, Parvizi J, Beck M, Leuning M, Notzli H, Siebenrock KA, Femoroacetabular impingement: a cause for osteoarthritis of the hip. Clin Orthop Relat Res. 2003;(417):112-20.

4. Amanatullah DF, Antkowiak T, Pillay K, Patel J, Refaat M, Toupadakis CA, Jamali AA. Femoroacetabular impingement: current concepts in diagnosis and treatment. Orthopedics. 2015;38(3):185-99.
5. Ganz R, Gill TJ, Gautier E, Ganz K, Krugel N, Berlemann U. Surgical dislocation of the adult hip a technique with full access to the femoral head and acetabulum without the risk of avascular necrosis. J Bone Joint Surg Br. 2001;83(8):1119-24.

6. Siebenrock KA, Wahab KHA, Werlen S, Kalhor M, Leunig M, Ganz R. Abnormal extension of the femoral head epiphysis as a cause of cam impingement. Clin Orthop Relat Res. 2004;(418):54-60.

7. Fairley J, Wang Y, Teichtahl AJ, Seneviwickrama M, Wluka AE, Brady SR, et al. Management options for femoroacetabular impingement: a systematic review of symptom and structural outcomes. Osteoarthritis Cartilage. 2016;24(10):1682-96.

8. Kuhns BD, Weber AE, Levy DM, Wuerz TH. The natural history of femoroacetabular impingement. Front Surg. 2015;2:58. 
9. Hoppe DJ, Sa D, Simunovic N, Bhandari M, Safran MR, Larson CM, Ayeni OR The learning curve for hip arthroscopy: a systematic review. Arthroscopy. 2014;30(3):389-97.

10. Souza BGS, Dani WS, Honda EK, Ricioli W Jr, Guimarães RP, Ono NK Polesello GC. Do complications in hip arthroscopy change with experience? Arthroscopy. 2010;26(8):1053-7.

11. Sardana V, Philippon MJ, Sa D, Bedi A, Lily Y, Simunovic N, Ayeni OR. Revision hip arthroscopy indications and outcomes: a systematic review. Arthroscopy. 2015;31(10):2047-55.

12. Horisberger M, Brunner A, Herzog RF. Arthroscopic treatment of femoral acetabular impingement in patients with preoperative generalized degenerative changes. Arthroscopy. 2010;26(5):623-9.

13. Smith-Petersen MN. Treatment of malun coxae sinilis, old slipped upper femoral epiphysis, intrapelvic protrusion of the acetabulum, and coxa plana by means of acetabuloplasty. J Bone Joint Surg Am. 1936;18:869-80.

14. Tonnis D, Heinecke A. Acetabular and femoral anteversion: Relationship with osteoarthritis of the hip. J Bone Joint Surg Am. 1999;81(12):1747-70.

15. Glick JM, Sampson TG, Gordon RB, Behr JT, Schmidt E. Hip arthroscopy by the lateral approach. Arthroscopy. 1987;3(1):4-12.

16. Valera M, Ibanes N, Sancho R, Tey M. Reliability of Tönnis classification in early hip arthritis: a useless reference for hip-preserving surgery. Arch Orthop Trauma Surg. 2016;136(1):27-33.
17. Zhang D, Chen L, Wang G. Hip arthroscopy versus open surgical dislocation for femoroacetabular impingement: a systematic review and meta-analysis. Medicine (Baltimore). 2016;95(41):e5122.

18. Piedade SR, Pinaroli A, Servien E, Neyret P. TKA outcomes after prior bone and soft tissue knee surgery. Knee Surg Sports Traumatol Arthrosc. 2013;21(12):2737-43.

19. Montgomery SR, Ngo SS, Hobson T, Nguyen S, Alluri R, Wang JC, Hame SL. Trends and demographics in hip arthroscopy in the United States. Arthroscopy. 2013;29(4):661-5.

20. Khan M, Habib A, Sa D, Larson CM, Kelly BT, Bhandari M. Arthroscopy up to date: hip femoroacetabular impingement. Arthroscopy. 2016;32(1):177-89.

21. Frank RM, Lee S, Bush-Joseph CA, Salata MJ, Mather RC 3rd, Nho SJ. Outcomes for hip arthroscopy according to sex and age: a comparative matched-group analysis. J Bone Joint Surg. 2016;98(10):797-804.

22. McCormick F, Nwachukwu BU, Alpaugh K, Martin SD. Predictors of hip arthroscopy outcomes for labral tears at minimum 2-years follow-up: the influence of age and arthritis. Arthroscopy. 2012;28(10):1359-64

23. Harris JD, McCormick FM, Abrams GD, Gupta AK, Ellis TJ, Bach BR Jr, et al. Complications and reoperations during and after hip arthroscopy: a systematic review of 92 studies and more than 6,000 patients. Arthroscopy. 2013;29(3):589-95. 